\title{
THE INTERNATIONAL LIBERAL ORDER PROSPECTS FOR THE TRANSATLANTIC PARTNERSHIP UNDER BIDEN'S ADMINISTRATION
}

\author{
Alexandra Monica NUNWEILLER BĂLĂNESCU, PhD \\ Center for Strategic Studies, National University of Political Studies and Public \\ Administration \\ Bucharest/Romania
}

\begin{abstract}
:
In recent years, new security challenges, risks and threats have emerged (including the increasing competitiveness of China and assertiveness of Russia), while domestic political, economic and societal changes have shifted priorities and policies both in the US and in Europe. Under these circumstances, the global security environment has dramatically changed, with the very stability of the liberal world order, established at the end of the Cold War, being at stake. The relationship between the world order and the transatlantic partnership is one of inter-dependency: on one hand, the partnership contributed to the establishment of the current world order and is vital to preserving it, or rather to rebuilding it so that it continues to reflect the Western community's core values and protect its strategic interests; on the other hand, it is itself shaped by the changes taking place in the world order. To determine the current status and role of the transatlantic partnership, as well as its prospects under the Biden administration (and beyond) I analyse the new security environment, the challenges it raises for the US and Europe and the divergences they generate, and I assess the relative position of the main actors in the new multi-polar system that is beginning to take shape.
\end{abstract}




\section{Keywords}

Autonomy; great power competition; Joe Biden; transatlantic partnership; world order.

\section{THE INTERNATIONAL LIBERAL ORDER}

The world order in this article is defined as a system of rules and values recognized as legitimate by the dominant powers in the system (thus being associated with the distribution of power in the system), while other units in the system either don't have the means to challenge it, either it serves their own interests, or they are simply "outside of the system"1. Among all the concepts associated with a world order, the principles recognized by the Westphalian Peace are the only ones acknowledged as being at the basis of the existing order (Kissinger 2014, 13). The contemporary Westphalian system, whose central and dominant power is now the United States, has sought to alleviate the anarchic nature of the world by creating an extensive network of international legal structures and organizations designed to facilitate international trade, to establish generally accepted dispute settlement principles and to set certain limits for the conduct of wars when they break out (Kissinger 2014, 13). In this article, I will refer to the world order installed after the end of the Cold War and the dissolution of the Soviet Union, as the "international liberal order". With the United States at the center of this order, Washington sets the international rules including through the international organizations it has established. The US is often the legislator, judge and "gendarme" on the contemporary international stage, but when its power and/or legitimacy are either challenged by other units in the system, or when it unilaterally moves away from these assumed roles, the stability of the international liberal order is threatened.

${ }^{1}$ A world order is not automatically global in the strict sense of the word (to encompass the whole globe in the system of rules and organizations it has built). 
Henry Kissinger wrote in 2014 that "in a world of geopolitics, the order established and proclaimed by Western countries as universal has reached a turning point" (239), and John Mearsheimer reinforced this point of view in 2019: "that order was destined to fail from beginning, because it contained the seeds of its own destruction"(7). Neither one of them associates the decline of the international liberal order with the person or policies of the former US President, but rather with the characteristics of the system itself, which is by definition anarchic and competitive, with unipolarity being the least stable form of international power distribution.

As mentioned in the working definition presented above, the stability of the world order can be reduced to two elements: legitimacy and balance of power, and any changes on these two dimensions can produce effects in the existing order. Legitimacy can be threatened from the outside (by units in the system which can be both partners and competitors that challenge the rules imposed in the current order), or from the inside (by the disengagement of the dominant power). Starting from the hypothesis that the current order "contains the seeds of its own destruction", Mearsheimer believes that the globalization process supported and promoted by the West was at the basis of the accumulating tensions within the liberal Western world $(2019,8)$. In his view, hyperglobalization, which has sought to minimize barriers to trade and global investment, has been the main driver of job losses, declining wages and rising income inequality throughout the liberal world, all of which also led to recurring financial crises. These issues soon turned into political issues, thus eroding support for the liberal order from within (Mearsheimer 2019, 8). Furthermore, Mearsheimer argues that a hyper-globalized economy undermines the order in another way: it helps countries other than the dominant one to become stronger, which can undermine unipolarity and destabilize the liberal international order $(2019,9)$. Mearsheimer (in line with neorealist theory) believes that the new world order that will emerge will be mostly realist in nature and will be centered around (great) power competition. Neorealists argue that bipolar or multipolar systems are associated with a realist word order, but even so, they do not consider that competition (or even rivalry) excludes cooperation, which is all the more true in a world as interconnected as 
that of today. As the existing order is increasingly challenged, the rules will have to be redefined as new centers of power appear in the system. The balance of power can be threatened by the accumulation of power by a state that refuses the role assigned, but ultimately the level of risk is directly linked to the ability of the dominant power(s) to either limit the power the respective unit accumulates or to handle the new reconfiguration of power and to adjust the balance. In most cases, from a historical standpoint, this can only be achieved through extensive networks of alliances and coalitions.

Apart from legitimacy and changes in the balance of power, the stability of a word order can also be threatened by black swan events (with low probability and high impact). Regarding the impact of COVID-19 on the international liberal order, opinions of political scientists vary greatly, from treating it as a simple inflexion point to forecasting the transformative changes it will entail (Pașcu, Nunweiller 2020,39). Stephen Walt believes that in the post-covid reality "the world will be less open, less free, less prosperous and more competitive than many anticipated just a few years ago" $(2020,3)$. The COVID-19 pandemic is currently accelerating previous trends, not overthrowing prior forecast (certainly not those of neorealist scholars), in the sense that is deepening international power competition and thus fast-tracking the transition to a multipolar, realist in nature, world order (Pașcu, Nunweiller 2020, 39).

Kissinger wrote back in 2014 that "as competition increases and new power centers emerge, rebuilding the international system becomes the most difficult challenge facing the current political class" $(2014,298)$. In 2021, I argue in this article, western alliances (current and prospective) are paramount in the process of rebuilding the international system, as none of the partners can individually manage the whole spectrum of emerging risks and challenges (including the rise of China and the increased assertiveness of Russia). If western allies cannot manage this rebuilding process, this mission will be undertaken by other emerging powers in the system and the new order will be designed to serve their own interests and reflect their own values. As the transatlantic partnership lies at the center of the current western system of alliances, deepening cooperation and rebuilding trust between the US and Europe is vital. By creating a "common pole of power" - term used in this article to describe an ideal 
hypothetical set of circumstances which will allow the US and EU to act on the international scene as a single bloc and speak with a single voice - partners on both sides of the Atlantic could preserve their privileged position in the international system and could jointly manage the process of rebuilding a new order that reflects their interests and values.

In the following chapters I analyse the new international security environment, the main divergences in the transatlantic partnerships, the relative position of the main actors in the current system and the role of NATO in this partnership.

\section{THE NEW SECURITY ENVIRONMENT}

In recent years, security risks and threats have multiplied and diversified, and their nature is now both conventional and hybrid. The risks and threats are generated by state and non-state actors coming - mainly - from the East and the South and can be summarized as follows: increasing the assertiveness of the Russian Federation in its vicinity, which mainly targets the eastern flank of NATO; the emergence of hybrid warfare; the multiplication and diversification of cyber-attacks; the instability in the South (Middle East and North Africa), which has led to major humanitarian crises, followed by a wave of refugees on European territory and an intensification of terrorist activity inside the European Union. These developments have led to an accelerated deterioration of the security situation at European and global level. The very nature of the conflict has changed, and its main feature now is its cross-border nature (in terms of the consequences it produces). The mechanisms and tools through which these risks and challenges can be managed are currently being adjusted (both at national, as well at the institutional level), but given their transnational nature, they require a coordinated approach between allies and partners.

At the same time, major political changes have and are taking place in both Europe and the United States, which are likely to lead to more instability. The economic and financial crisis of 2008 has generated a wave of dissatisfaction and mistrust among Western citizens affected by the crisis that did not go away after the end of the crisis. Foa and Mounk claim that citizens in Western democracies 
in general are increasingly turning away from democracy as they "have become more cynical about the value of democracy as a political system, less hopeful that anything they do might influence public policy, and more willing to express support for authoritarian alternatives" (2016, 6-7). Citizens' dissatisfaction has fueled populist and anti-globalization policies on both sides of the Altlantic and paved the way for protectionist policies, thus leaving room for other powers to manifest themselves on the regional and global stage. While the transatlantic powers are still facing the shock waves of the economic and financial crisis, as well as new security risks and threats, other states - such as China and Russia are developing their economic and military capabilities and showing revisionist tendencies.

The erosion of US's military, economic and political power - even if only in relative terms - calls into question the very foundations of the current world order (Friedman Lissner and Rapp-Hopper 2018, 12), especially in the context of the emergence of revisionist powers that do not share the liberal values promoted by the US. Despite the fact that Washington remains - in the short and medium term - the main global power at a considerable distance from other emerging powers (Kotkin 2018, 14), the distribution of power on the international stage has become more diffuse and signals an emerging reconfiguration of the international order, which poses additional challenges for the Euro-Atlantic region on all dimensions of its policies (Zieba 2018, 60). In a 2014 Brookings Institute report, the issue of redistribution of power in the international system is examined in close connection with political rivalry and with the risk of conflict between great powers (Jones and al. 2014). There seems to be a broad consensus among researchers that changes in distribution of power and impending changes in polarity would lead towards a more realist global order.

The issue of international power redistribution goes beyond strictly academic concerns, and is mentioned and analysed in various official of the European Union. As early as 2015, it is clearly stated in the Strategic Review published by the EU's External Action Service (EEAS) that "the world system is no longer bipolar, unipolar and not even multipolar, but the very notion of polarity is called into question". This document also marks the starting point of a new, 
unprecedented momentum for EU's Common Security and Defence Policy (CSDP) with the stated objective for the EU to further its role as a global actor by enhancing its strategic autonomy. In contrast, there are no mentions of shifts in polarity in US's recent strategic or defence strategies, but there is a relevant mention to power distribution in Biden's Interim National Security Strategic Guidance: "We must also contend with the reality that the distribution of power across the world is changing, creating new threats" (2021, 7-8).

Due to changes in the structure of the international system, but also in the regional and global security environment, the European Union had to adapt to avoid becoming "irrelevant" as a global player ${ }^{1}$, and to achieve this goal a certain level of strategic autonomy is vital. After the European Council stated unequivocally in December 2013 that "defense matters" and after Junker took over the presidency of the European Commission, a stronger Europe in the field of security and defense has become one of the Commission's 10 top priorities. The crucial moment in the development of European Security and Defense was in June 2016, with the presentation of the strategic document "Common vision, common action: A stronger Europe. A Global Strategy for the European Union's Foreign and Security Policy "by the High Representative / HR Federica Mogherini. As analysed in the next chapter, a stronger CSDP is also vital for NATO and for the transatlantic partnership.

\section{EU, NATO AND THE TRANSATLANTIC PARTNERSHIP}

EU and NATO share the same values, interests and have common members, but until recently, they did not share similar responsibilities. New European approaches to security and defense have led to a number of misunderstandings between partners about the new responsibilities assumed by the EU, as well as potential overlaps that could result from them. Despite the fact that the two

${ }^{1}$ Extrapolation from the theory presented by Ries that an organization does not adapt to the new environment, it risks being replaced / eliminated by other organizations or other actors (Ries, 2017, 150-160). 
organizations have an essentially different basic mission - as NATO is a military alliance and the EU is not (Pașcu Report 2018) - the new level of ambitions for reaching strategic autonomy, coupled with the lack of a formal and permanent EU-NATO communication and cooperation framework, can generate a series overlaps in terms of skills, resources, policies and area of action. Such overlaps can lead three results: rivalry, cooperation or both (competitive cooperation, also referred to as "coopetition"1).

Joachim Koops advances the idea that when an organization assumes similar but secondary - responsibilities to those of another organization whose "raison d'être" are precisely those responsibilities, and there are already a number of important overlaps between the two organizations, especially in terms of resources, the most plausible scenario is cooperation (2019, 326). Security and defense are NATO's core responsibilities, while for the EU those are secondary tasks. The EU is essentially a political and economic organization, and security and defense are relatively more recent priorities on the Brussels agenda. As an argument in favour of Koops, in practice there is an increasingly obvious division of responsibilities between the two organizations in the field of security: NATO is primarily concerned with external security, while the EU is concerned with internal security. However, Biermann believes that the inherent tendency of organizations is to maintain their autonomy and minimize their dependence, so that rivalry is always a possibility $(2008,167)$. The EU's ambition and efforts towards strategic autonomy, coupled with US's (and even NATO) reactions to them, serve as arguments in favour of the idea postulated by Biermann. Given that there are valid arguments in favour of both points of view, in this article I advance a middle ground, namely that of competitive cooperation, or "coopetition". By "coopetition", I refer to the relationship between two actors in the international system, who, depending on their interests and objectives, may

1 Though initially coined to describe simultaneous competition and cooperation in business(es), its larger definition can be summed up as a strategy that goes beyond the conventional rules of competition and cooperation to achieve advantages of both parties (Brandenburger and Nalebuff, 1998). This can also be applied to global (power) competition. 
choose to cooperate in certain areas and act unilaterally on divergent issues, if the negotiations have not favoured a harmonization of policies adopted on those issues. However, it can only work if the major interests converge and each organization respects the mandate and essential responsibilities of the other. The purpose of this relationship between two relevant actors that share similar interest and values is to avoid a Zero-Sum game by designing fit-for-purpose strategies that go beyond traditional rules of competition and to achieve advantages (in terms of relative power and relative gains) for both actors, while discouraging competitors (strength in numbers).

The EU and NATO have common values, (mostly) converging interests and a single set of capabilities (considering the fact that the two organizations share 21 members). At the same time, they have different tools by the nature of their basic mission, which - through coordination - can be complementary. Neither organization has all the tools on its own to manage the whole spectrum of current threats and challenges, which are increasingly diverse and less conventional. Furthermore, tactical losses (in theaters of operations), strategic losses (potential destabilization of the rapid reaction capacity of both organizations), but also economic losses (doubling of capabilities) that could result from a potential rivalry between the two organizations would reduce the competitiveness of both partners and would weaken the position of individual actors (EU members and/or NATO allies). At the same time, the EU and the US, given the extent of the partnership and the common areas of action, may have different objectives on specific issues (the most recent examples being the withdrawal from Afghanistan and the creation of AUKUS'). Therefore, a permanent convergence of goals and interests is not possible in a complex security environment, so treating cooperation and competition as mutually

1 A military alliance between Australia, the United Kingdom and the United States announced on 15 September 2021 and created with the purpose to maintain stability in the Indo-Pacific region. Its creation was not favourably met by European leader (the EU as a whole and all EU member states being completely left out of it), and by France in particular (as it includes the supply of nuclear-powered submarines to Australia, displacing a previous contract with France). 
exclusive would lead to permanent blockages in the partnership (which happened on multiple occasions during the Trump presidency).

At EU level, there is substantial political support for intensifying EU-NATO cooperation. In June 2018, the European Parliament adopted the Paşcu report on EU-NATO relations, which emphasizes that the two organizations are essential for ensuring the security of European citizens in the context of a deteriorating security environment. At the same time, the report underlines that a strengthened partnership between the EU and NATO is also a means for strengthening transatlantic cooperation, at a time when it's facing multiple challenges. The intensification of the EU-NATO partnership is supported by senior NATO officials, SG/NATO Jens Stoltenberg has repeatedly said that EUNATO cooperation and EU efforts to develop a common European security and defense can "increase security for us all" (NATO press conference 2018). Regarding the transatlantic partnership, Jens Stoltenberg wrote an article in The Guardian in 2018 in which he reiterated the importance of transatlantic relations for the peace and prosperity of both continents, called for unity, but also expressed his own uncertainties related to the future of transatlantic relations on the background of tensions between the US and the EU: "There are real differences between the US and other allies on issues such as trade, climate change and the nuclear deal with Iran. These differences are real and will not disappear overnight. Nowhere is it written in stone that the transatlantic link will always prosper" (Stoltenberg 2018). The differences on these issues were specific to the Trump era, and Biden reversed Trump's policies on all the dimensions mentioned above. However, in the current geopolitical context discussed above, the EU and the US do not share common goals on all coordinates of transatlantic cooperation, so that for the partnership to thrive, it is necessary for partners to continue cooperation in certain areas of vital interest for all parties, while acting unilaterally in others. However, this scenario of competitive cooperation is possible only if the objectives of one do not harm the vital interests of the other and only if the intentions and positions of each party are known to the other.

The EU-NATO Joint Declaration (2016) laid out a comprehensive set of concrete actions to be undertaken by both organizations to intensify cooperation and to 
achieve better complementarity. This marked the recognition of developments in the strategic environment as a threat to both organizations, but also of the necessity to strengthen cooperation in order to tackle them. Furthermore, this joint declaration (and those that followed) could be - if political will exists - a first step towards the development of a common strategic culture, with a standardized threat perception assessment as its cornerstone. While measures undertaken in the last five years have positively contributed to an enhanced EUNATO cooperation on specific topics, and even contributed to the endurance of the transatlantic partnership during Trump's presidency, the development of a true common strategic culture relies on the political will of state actors from both organizations, as security and defence are largely fields of national sovereignty.

\section{US'S POSITION AND POSTURE - FROM TRUMP TO BIDEN}

Joe Biden first formally presented (as presidential candidate) his vision of America's role in the world in an article published in "Foreign Policy" in 2020. His plan was to rebuild the foundation of American power by invigorating domestic democracy and by recalibrating the international partnerships of which the United States is a part (believing that these two are mutually reinforcing). While his vision is certainly different from Trump's in what concerns the preference for multilateralism, it is not innovative in comparison with previous administrations as it heavily relies on American exceptionalism and on the central role of the US on the global stage, including vis-à-vis its partners: "We must once more harness that power and rally the free world to meet the challenges facing the world today. It falls to the United States to lead the way. No other nation has that capacity. No other nation is built on that idea. We have to champion liberty and democracy, reclaim our credibility, and look with unrelenting optimism and determination toward our future" (Biden 2020). Joe Biden's success in the 2020 presidential election indeed marked a return to a 
more traditional diplomacy, especially in regard to the system of alliances that propelled the United States to the privileged position it (still) currently holds in the international system. Drawing some preliminary conclusions from his first 8 months in office, Biden seems committed to promoting the United States as an actor that respects liberal democratic values and the rules of the international system, while stressing the importance of the transatlantic partnership. So far, most efforts have been mostly diplomatic in nature, such as the change of rhetoric from "America First" to "America is Back" (in world leadership), doubled mostly by his availability to participate (physically or virtually) to a series of events and conferences with his European counterparts and to (re)engage the US to a series of multilateral treaties that Trump opted out of (such as the Paris Agreement on climate change and the World Health Organization). This change of rhetoric and the efforts to change Washington's image in the world after Trump's presidency, while important in terms of perception, do not guarantee that the US is ready or willing to make concrete compromises to substantially renew or strengthen the transatlantic partnership. The biggest (so far) foreign policy decision of the new administration was made unilaterally - to withdraw all forces from Afghanistan in august 2021 - with little concern for its allies and partners. This decision produced two major effects regarding US-Europe relation: 1. it shook the confidence of Europeans in Joe Biden's ability to set priorities, as well as in the decision-making process of his administration (Tharoor 2021); 2. it made Europeans more cautious in associating themselves with the US in multinational military operations, as they have done so far, and thus it increased the likelihood of European having to intervene independently in crisis management in their own neighborhood. On the other hand, recent events in Afghanistan have shown once again that Europeans do not yet have the capacity to act effectively independently from Washington (Puglierin 2021), as even for the withdrawal of their own troops they heavily relied on US capabilities.

US's foreign and security policy is dependent on a series of factors, balance of power and power competition being among them. While the US is still the predominant power, it is no longer uncontested, thus its interests shifted and became narrower (as detailed below). As it now faces direct threats and 
challenges, the US is concentrating its power and efforts to countering those and is less incline to intervene where its vital interests are not directly targeted. While Biden has a different strategy and a more traditional diplomacy compared to Donald Trump, US's interests did not change dramatically. For example, while some have associated US's disengagement with Trump's administration, this policy was adopted during the Obama administration (with the "pivot" to Asia), was continued by Trump and now by Biden. While the means have changed from one administration to the other, the way in which the US defines its vital interest did not. To clarify this, I will next analyse the ruptures and the elements of continuity in terms of foreign and security policy options from Trump to Biden, including in terms of the differences and similarities between the 2017 National Security Strategy and the Interim National Strategic Guide, published by the Biden administration in March 2021.

The challenges to US national security posed by China, Russia, Iran and North Korea as well as international terrorism remained top concerns under the Biden administration, which represents a strong element of continuity with the Trump administration's 2017 shift to great power competition (Soare, 2021, 15). What marks a rupture are the means the new administration envisioned to use to manage these challenges, mainly diplomacy: " In advancing America's interests globally, we will make smart and disciplined choices regarding our national defense and the responsible use of our military, while elevating diplomacy as our tool of first resort" (Interim National Security Strategic Guidance 2021, 14). In the National Security Strategy of 2017, "competitive diplomacy" (as it appears in the official document) is intrinsically linked to US's ability to project power outside its borders, thus stressing its deterrence component: " Diplomacy is indispensable to identify and implement solutions to conflicts in unstable regions of the world short of military involvement. It helps to galvanize allies for action and marshal the collective resources of like-minded nations and organizations to address shared problems" (National Security Strategy of the United States of America, 2017, 33). In this document, diplomacy is definitely not envisaged as a tool of first resort, as the focus is placed on deterrence and military capabilities: "The United States must retain overmatch-the combination of capabilities in sufficient scale to prevent enemy success and to 
ensure that America's sons and daughters will never be in a fair fight. Overmatch strengthens our diplomacy and permits us to shape the international environment to protect our interests." (National Security Strategy of the United States of America 2017, 28).

Another breaking point from Trump's strategy is Biden's preference for multilateralism, but on US's terms and under its leadership (with a strong reliance on American exceptionalism): "The United States must lead by the power of our example"(Interim National Security Strategic Guidance 2021,7); "In addition to recommitting to our alliances and partnerships, the United States will again embrace international cooperation(...). We will move swiftly to earn back our position of leadership in international institutions"(11); "In a significant number of issues(...) effective global cooperation and institutional reform are needed for America to resume a leadership role in multilateral organizations" (13); "By restoring US credibility and reasserting forward-looking global leadership, we will ensure that America, not China, sets the international agenda, working alongside others to shape new global norms and agreements that advance our interests and reflect our values"(20). As stated in the interim strategy, US is planning on (re)taking a leadership role in the multilateral formats of which it is a part, which inherently limits the possibility of an equal partnership with any other unit(s) in the system, the EU included.

As Biden approaches the final quarter of his first year as US president, his sheer determination to deliver on his own foreign policy priorities is apparent, as are the implications of them for the closest partners of the US (Vinjamuri 2021). During his address at the 76th UN General Assembly, he reconfirms his strong preference for multilateralism and brings further nuances to US's leadership role: "We will lead together with our allies and partners". At the same time, he states that "The mission must be clear and achievable and(...), whenever possible, in partnership with our allies". As his statement indicates, as well as the foreign policy decision of his administration, Biden's multilateralism is a pragmatic one. The most recent example in this sense is Washington's decision to create AUKUS, thus choosing among its partners those who share (and could better serve) its interests, even if - in this particular case - it meant leaving out the EU and facing strong backlash from Paris. As a potential positive outcome, this 
pragmatic multilateralism could create the right circumstance for a working "coopetition", but only if the EU is willing to work more towards achieving a greater strategic autonomy and thus relying less on the US as a guarantee for its own security and stability.

\section{CONCLUSIONS}

The transatlantic partnership is vital not only for ensuring the security of allies from both sides of the Atlantic, but also to maintaining the international liberal order. This order was established at the end of the Cold War at it was a direct consequence of US's involvement in shaping it. In this process, the European partners have played a major role by supporting the policies adopted by Washington and by recognizing the legitimacy and status of the US as the legislator and the "gendarme" of the new system of rules. Divergences between partners in this situation, coupled with the manifestation of revisionist tendencies by regional actors, represents an increased risk to the stability of the world order. While the interests of partners are divergent on several issues, and perceptions of threats also differ, the common interest is to maintain the order or to reshape it, so that it continues to safeguard their privileged status on the international arena.

The first eight months of Biden's presidency have showed that 1 . The manner in which the US defines its national interests goes beyond domestic political changes and it's intrinsically linked to changes produced on the international arena; 2 . These interests become narrower as the power on the global stage becomes more diffused; 3 . The main divergences in the transatlantic partnership were not a direct consequence of Trump's presidential term and cannot be solved just by a change in leadership (on any side of the Atlantic). Biden's unilateral decision to withdraw all forces from Afghanistan reconfirmed to its European partners and allies that they can no longer rely on the "US guarantee" and that they have to take more responsibility for their own security and defence, but also for the stability in its own neighborhood. In an ideal scenario, the EU will step up its efforts to develop its strategic autonomy in close 
cooperation with the United Kingdom in order to create a solid NATO pillar in Europe, while also increasing its contributions to the Allied budget. In a pessimistic scenario, the EU will choose to continue to rely solely on the US guarantee, fixed in patterns that no longer apply, and will try to maintain the old "transatlantic bargain" in which Washington sets the strategy, secures most of the resources, and Europe follows its lead. If we at the past 60 years, the second scenario is more likely, but it involves more risks than ever (for European mostly) giving the geostrategic changes that are now taking place on the international stage.

\section{REFERENCES}

- Biermann, Rafael and Koops, Joachim. 2016. The Palgrave handbook of interorganizational relations in world politics. London: Palgrave Macmillan.

- Biermann, Rafael. 2008. Towards a theory of inter-organizational networking: the Euro-Atlantic security institution interacting. Review of international organizations 3(2).

- Biden, Joe. 2020. Why America Must Lead Again: Rescuing US Foreign Policy after Trump. Foreign Affairs. Accessed May 2020. https://www.foreignaffairs.com/articles/united-states/2020-01-23/whyamerica-must-lead-again.

- Biden addresses at the 76th UN General Assembly (full transcript). 2021. https://abcnews.go.com/Politics/full-transcript-biden-addresses-76thgeneral-assembly/story?id=80146170.

- Brandenburger, Adam, Nalebuff, Barry. 1998. Co-opetition: 1. A revolutionary mindset that combines competition and co-operation; 2. The game theory strategy that's changing the game of business. New York: Crown Business.

- Foa, Roberto Stefan and Yasha, Mounk. 2016. The Dangers of Deconsolidation. Journal of Democracy. 27: 5-17.

- Friedman Lissner, Rebecca, Rapp-Hooper, Mira. 2018. The Day after Trump: American Strategy for a New International Order. The Washington Quarterly. 41:1. 
- Interim National Security Strategic Guidance. 2021. https://www.whitehouse.gov/wp-content/uploads/2021/03/NSC1v2.pdf.

- Joint declaration by the President of the European Council, the President of the European Commission, and the Secretary General of the North Atlantic Treaty Organization. 2016 (updated December 2017). https://www.nato.int/cps/en/natohq/official_texts_133163.htm.

- Jones, Bruce, Wright, Thomas, Shapiro, Jeremy, Keane, Robert. 2014. The state of International Order Policy Paper. Brookings Institute. https://www.brookings.edu/research/the-state-of-the-internationalorder/.

- Koops, Joachim. 2017. Theorizing inter-organizational relations: the EUNATO relationship as a catalytic case study. European Security. 26:3.

- Kotkin, Stephan. 2018. Realist world. The Players change, but the Game Remains. Foreign

Affairs. https://www.foreignaffairs.com/articles/world/2018-06-14/realist-world.

- Kissinger, Henry. 2014. Ordinea mondială. Reflecții asupra specificului națiunilor și a cursului istoriei [World Order. Reflections on the Character of Nations and the Course of History].București: Editura Rao.

- Mearsheimer, John. 2019. Bound to fail. The Rise and Fall of the Liberal International Order. International Security. Vol. 43. No. 4.

- National Security Strategy of the United States of America. 2017. https:// www.google.com/ url? sa $=t \& r c t=j \& q=\& e s r c=s \&$ source $=$ web\&cd $=\&$ ved=2ahUKEwiY_MuXjLH0AhVc7rsIHYi_AL4QFnoECAIQAQ\&url=https $\% 3 \mathrm{~A} \% 2 \mathrm{~F} \% 2 \mathrm{Ftrumpwhitehouse.archives.gov} \% 2 \mathrm{Fwp}-$ content $\% 2$ Fuploads $\% 2$ F2017\%2F12\%2FNSS-Final-12-18-20170905.pdf\&usg=AOvVaw0pFCq55-G5Vs2jcPvH5-vb.

- Pașcu, Ioan Mircea, Nunweiller-Bălănescu, Alexandra Monica. 2020. Implications of the COVID-19 pandemic. EUROPOLITY. Continuity and Change in European Governance .vol.14. no.2.

- Pașcu report on EU-NATO relations (A8-0188/2018). 2018. https://www.europarl.europa.eu/doceo/document/A-8-20180188_EN.html.

- Press conference by NATO Secretary General Jens Stoltenberg following the meeting of the North Atlantic Council (NAC) in Defence Ministers' session. 2018. https://www.nato.int/cps/en/natohq/opinions_155268.htm. 
- Puglierin, Jana. 2021. Security and Defence. The fall of the Afghan government and what it means for Europe. European Council of Foreign Relations. Accessed 26 August 2021. https:/ / ecfr.eu/publication/the-fall-ofthe-afghan-government-and-what-it-means-for-europe/.

- Soare, Simona. 2021. Biden's Security Policy: Democratic Security or Democratic Exceptionalism?. Intereconomics. Volume 56. No 1.

- Stoltenberg, Jens. 2018. Europe and North America need to stay united now more than ever. The Guardian, Accessed 19 June 2018, https://www.theguardian.com/commentisfree/2018/jun/19/europenorth-america-nato-storm-political-risk.

- Strategic Review - The European Union in a changing global environment. 2015. Accessed June 2016. http://eeas.europa.eu/docs/strategic_review/eu-strategicreview_strategic_review_en.pdf.

- Tharoor, Ishaan. 2021. As U.S. leaves Afghanistan, Europe sours on Biden. Washington Post. Accessed 12 September 2021. https://www.washingtonpost.com/world/2021/08/31/europe-americashift-afghanistan/.

- Vinjamuri, Leslie. 2021. Leslie, Biden's realism will drive competition among US allies, Chatham House. Accessed 23 September 2021. https:// www.chathamhouse.org/2021/09/bidens-realism-will-drivecompetition-among-us-allies.

- Walt, Stephen. 2020. The Global Order After Covid-19. Vienna: Institut für Sicherheitspolitik.

- Zieba, Ryszard. 2018. The Euro-Atlantic Security System in the 21st Century. From Cooperation to Crisis. Switzerland: Springer. 